\title{
Variations in hydrostratigraphy and groundwater quality between major geomorphic units of the Western Ganges Delta plain, SW Bangladesh
}

\author{
Md. Ilias Mahmud ${ }^{1} \cdot$ Sarmin Sultana $^{2} \cdot$ M. Aziz Hasan ${ }^{2} \cdot$ Kazi Matin Ahmed $^{2}$
}

Received: 16 August 2015 / Accepted: 14 June 2017/Published online: 21 June 2017

(c) The Author(s) 2017. This article is an open access publication

\begin{abstract}
Relationships among geomorphology, hydrostratigraphy, and groundwater quality with special emphasis on arsenic and salinity have been analyzed in the Bangladesh part of the Western Ganges Delta (WGD). On the basis of the presence of characteristic geomorphic features, the study area is divided into two geomorphic units: fluvial deltaic plain (FDP) and fluvio-tidal deltaic plain (FTDP). Lithostratigraphic sections demonstrate that FDP is composed predominately of sandy material whereas FTDP is characterized by alternation of sand and clay/silty clay material. Hydrostratigraphically, FDP is characterized as a single aquifer system, whereas FTDP is a complex multi-aquifer system. Spatial distributions of arsenic concentrations in groundwater reveal that elevated arsenic $(>0.01 \mathrm{mg} / \mathrm{l})$ occurs mostly in the FDP. Occurrences of high arsenic in deeper part of the aquifer $\operatorname{system}(>100 \mathrm{~m})$ in the FDP, particularly in the south-western part, is probably due to the absence of any prominent impermeable layer between the shallow and deeper part of the aquifer system. Distributions of chloride concentrations show an increasing trend in groundwater salinity from north to south, i.e., from FDP to FTDP.
\end{abstract}

Md. Ilias Mahmud

mdiliasm1988@gmail.com

Sarmin Sultana

sarmin@du.ac.bd

M. Aziz Hasan

mahasan@du.ac.bd

Kazi Matin Ahmed

kmahmed@du.ac.bd

1 Department of Geology and Mining, University of Barisal, Barisal 8200, Bangladesh

2 Department of Geology, University of Dhaka, Dhaka 1000, Bangladesh
Keywords Geomorphology · Hydrostratigraphy ·

Groundwater · Arsenic · Salinity · Western Ganges Delta

\section{Introduction}

The Ganges Delta plain, the southwestern portion of the Bengal Basin, is mainly formed by channel-interchannel and overbank deposits of the river Ganges and its numerous tributaries and distributaries (Alam et al. 2003; Ravenscroft 2003). The recent sedimentation in the plain has been largely controlled by Holocene sea-level change leading to formation of several surface features (Ravenscroft 2003). Topographically, a gently sloping (between 0.05 and $0.01 \mathrm{~m} / \mathrm{km}$ ) fluvial area in the northern region grates to the nearly flat (less than $0.01 \mathrm{~m} / \mathrm{km}$ ) setting in the south where ground elevation is $<1 \mathrm{~m}$ above MSL (Shamsudduha et al. 2009). The extensive floodplain of the Ganges Delta is characterized by agricultural and agro-based socio-economic activities where the geological set up and the tectonic events indicate that the geomorphic characteristics are the key factors which form the most fertile land (Jha and Bairagya 2011). Groundwater provides over $90 \%$ of drinking water, and about $70 \%$ of irrigation supplies in this region (Hasan et al. 2007). However, excessive arsenic and salinity in groundwater adversely affects human health and threatens the yield of irrigated crops across the widespread floodplains of the Ganges (BGS/DPHE 2001; Smedley and Kinniburgh 2002; Das et al. 2009; Brammer and Ravenscroft 2009; Ravenscroft et al. 2009).

The aquifer system in the Ganges Delta occupies the uppermost few hundred meters of the stratigraphic sequence (Hoque et al. 2011) and the hydrogeological structure of the aquifer system is determined by the Pleistocene to Holocene evolution of the Basin (Hoque 
Fig. 1 Location map of the study area (redrawn after Rogers et al. 2013)

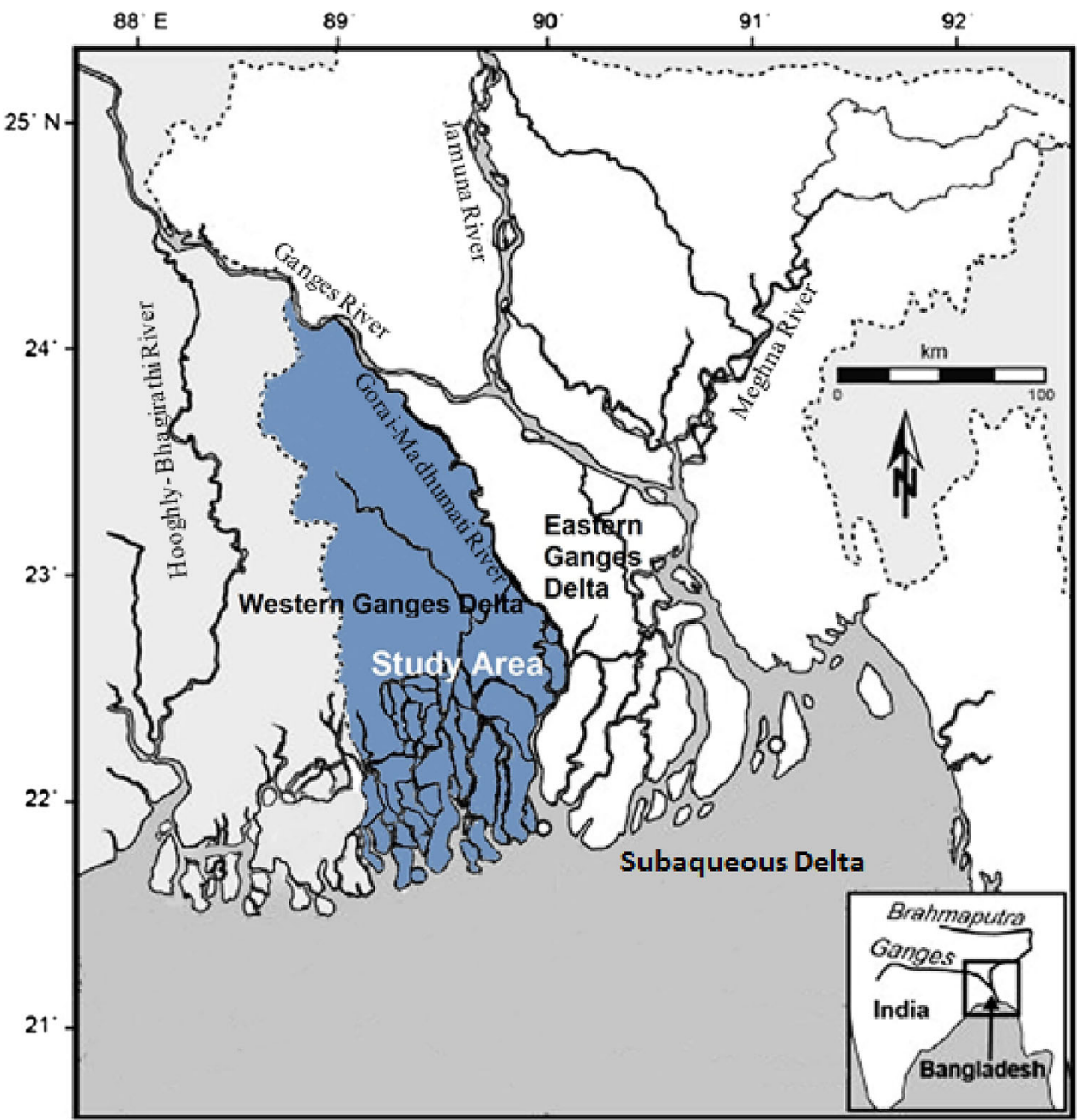

2010; Burgess et al. 2010) integrating a long history of fluvial/deltaic deposition (Ravenscroft 2003), basin subsidence (Goodbred and Kuehl 2000) and erosion occurring in channels and interfluves across the floodplain (Hoque et al. 2011). Collectively, these processes permitted the preservation of many hundred meters of the permeable sediments. The quality of groundwater in the plain has been influenced by late Quaternary stratigraphy, geomorphology and sedimentation (Ahmed et al. 2004; Mukherjee 2006; Acharyya and Shah 2007; Hasan et al. 2007; Muley et al. 2010). Examples can be drawn from the variation in degree of As enrichment in groundwater in different geomorphic units of the Ganges Delta (Ravenscroft 2001; Ahmed et al. 2004); availability of good aquifers in Quaternary sediments of Bangladesh and As-enrichment in Holocene alluvial aquifers (Ahmed et al. 2001; McArthur et al. 2001).

The strategic importance of groundwater in the Bengal Basin has prompted several hydrogeolgical (e.g., Burgess et al. 2002; Cuthbert et al. 2002; JICA 2002; van Wonderen 2003; Nishat et al. 2003; Harvey et al. 2006) and hydrostratigraphic analyses (e.g., Ravenscroft et al. 2005; Mukherjee et al. 2007; McArthur et al. 2008; Michael and Voss 2008; Burgess et al. 2010; Biswas et al. 2014; Ghosal et al. 2015). However, comparative studies to delineate hydrostratigraphic and groundwater quality variations in different geomorphic units in the Ganges Delta are still lacking. Even a complete geomorphological map of the

Table 1 Geomorphic units of the study area

\begin{tabular}{ll}
\hline Major geomorphic units & Geomorphic features \\
\hline Fluvial or upper deltaic plain & Natural levee \\
& Backswamps \\
& Meandering scrolls \\
& Ox-bow lake \\
& Channel bar \\
& River flood plain \\
& Other wetland \\
Fluvio-tidal or lower deltaic plain & Mangrove swamp \\
& Tidal flood plain \\
\hline
\end{tabular}


Ganges Delta is not available. In this paper, authors attempt to identify the major geomorphic units in Bangladesh portion of WGD and the variations in hydrostratigraphy and groundwater quality between them.

\section{The study area}

The investigated area forms the western part of the Ganges Delta and is included in the southwestern portion of the Bengal Basin (Fig. 1). The Gorai-Madhumati river separates the Western Ganges Delta from Eastern Ganges Delta. The extent of WGD has been considered to be bounded by the Bhagirathi-Hooghly river on the west and the Gorai-Madhumati river on the east. The Western
Ganges Delta (WGD) covers more than $65,000 \mathrm{~km}^{2}$ of the present-day Bangladesh and parts of adjacent West Bengal state of India. But the research work only focused on the Bangladesh portion of the WGD. The area lies between longitudes $88^{\circ} 00^{\prime} \mathrm{E}$ and $90^{\circ} 00^{\prime} \mathrm{E}$ and latitudes $21^{\circ} 15^{\prime} \mathrm{N}$ and $24^{\circ} 40^{\prime} \mathrm{N}$ with an area of $22,285 \mathrm{~km}^{2}$.

\section{Materials and methods}

Various types of data were collected from different sources. Satellite imagery was obtained from GLOVIS (www. glovis.gov.us). Five images of Landsat 8 that cover the study area, dated March 2014, were selected considering
Fig. 2 Geomorphological map of the study area

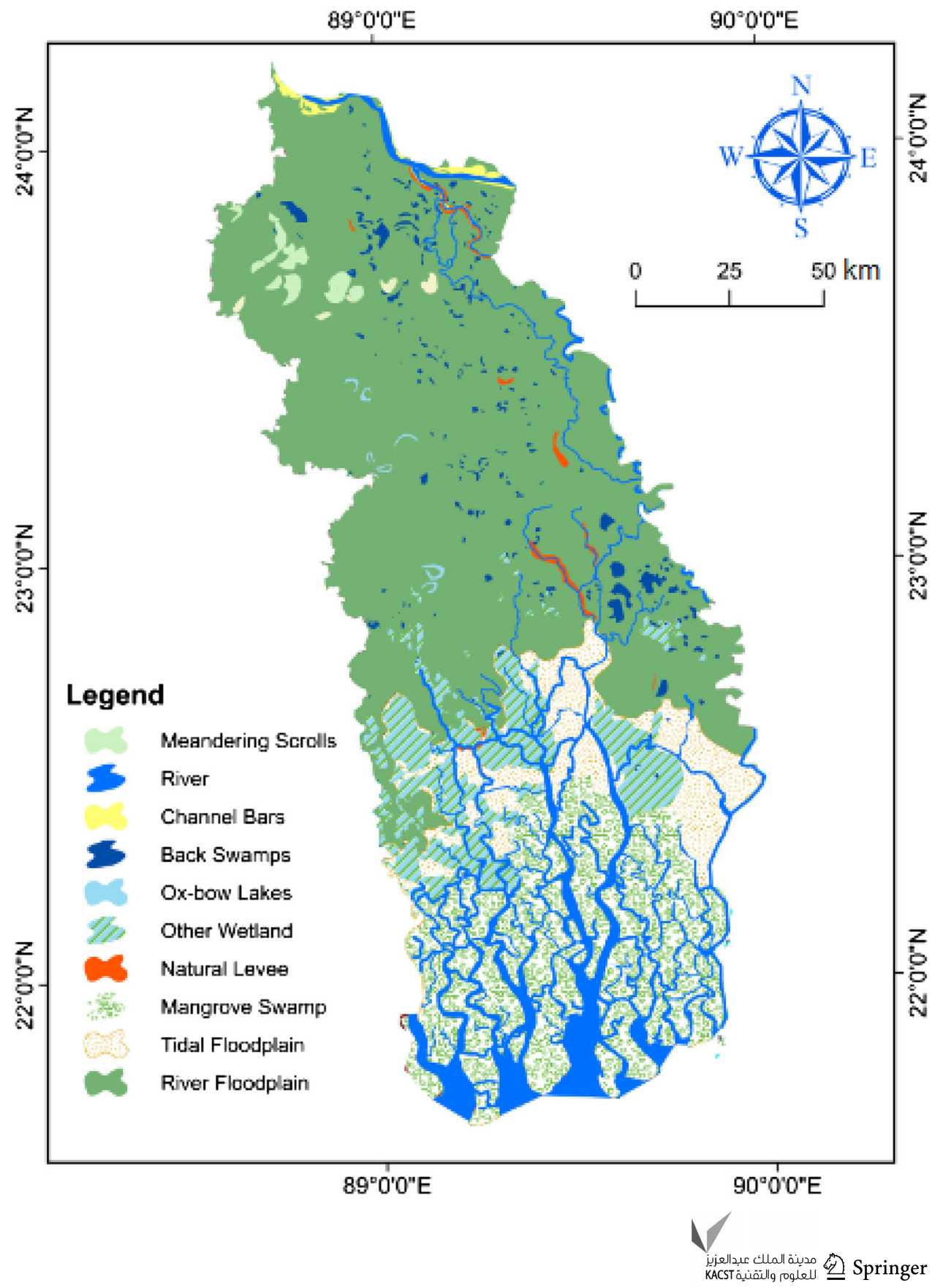


the spectral and spatial resolutions for geomorphological analysis. Lithologic data were collected from 1080 wells drilled in the study area by the Department of Public Health Engineering (DPHE), Bangladesh for hydrostratigraphic analysis. 642, 615 and 651 groundwater quality data, respectively, on arsenic (As), chloride $\left(\mathrm{Cl}^{-}\right)$and iron $\left(\mathrm{Fe}^{2+}\right)$ along with depth and location information were also collected from the DPHE for mapping special and depth characteristics of groundwater quality.

Geomorphic features were identified by visual analysis of satellite images through combined observation of shape, tone, texture, location extent and unsupervised image classification, together with the use of normalized difference vegetation index (NDVI). Image pre-processing and processing were performed using ERDAS IMAGINE 9.2 (ERDAS IMAGINE, Leica Geosystems Geospatial Imagine, LLC). All identified features were digitized to a common coordinate system, overlapped and presented using ArcGIS 10 (ESRI ArcGIS, Redlands, CA: Environmental Systems Research Institute) to produce a geomorphological map. Borelog and groundwater quality data were organized in Excel Spreadsheets (Microsoft Corporation, 2010). Based on litholog data, two north-south and three east-west manually interpolated lithologic cross sections were produced with RockWorks15 (Rockware, Golden, Colo., USA) to illustrate detailed depictions of the
Fig. 3 Major geomorphic units of the study area

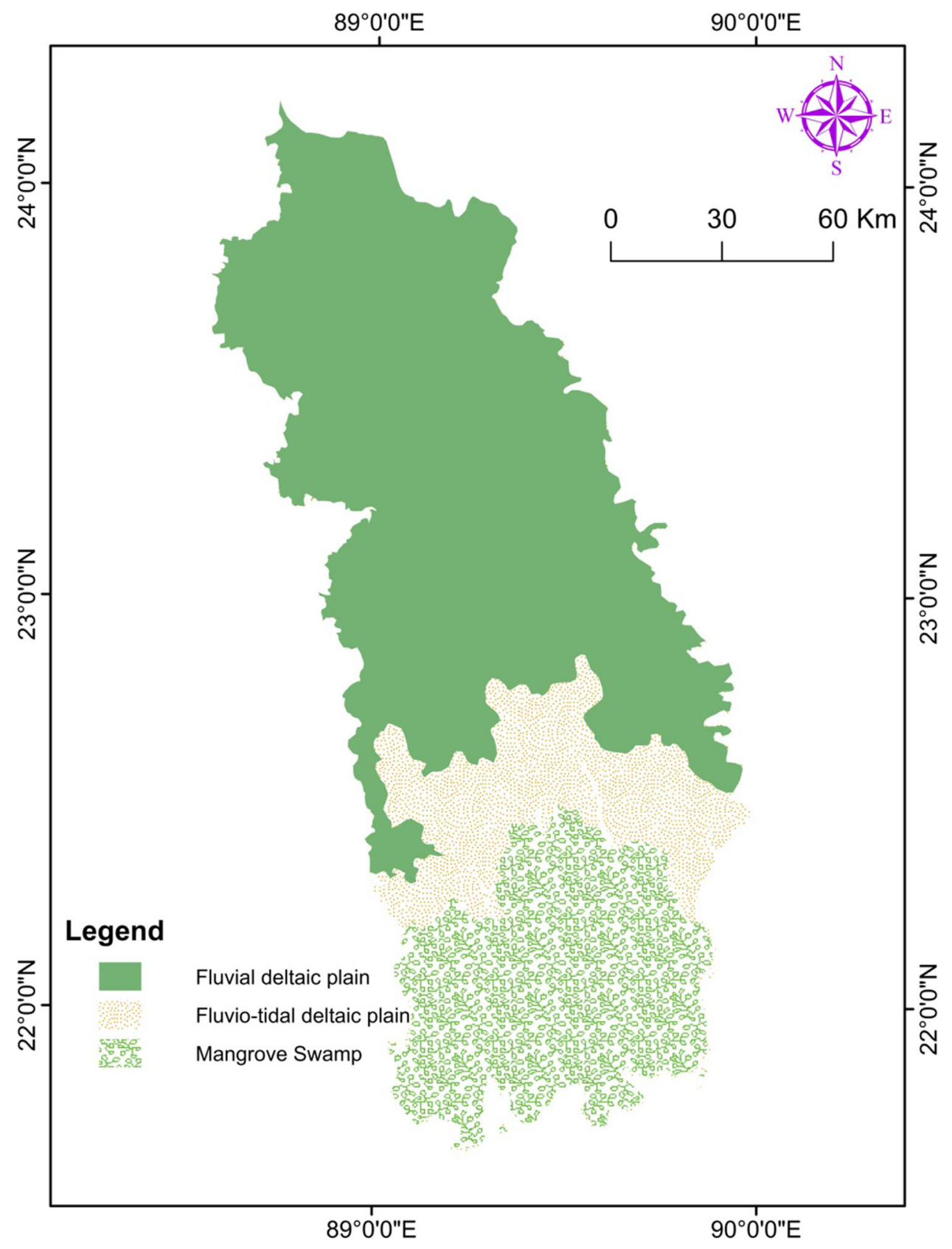


aquifer framework. Groundwater quality data were imported into ArcGIS 10 to decipher both spatial and vertical variability of the considered quality parameters.

\section{Results and discussion}

\section{Identification of geomorphic features}

The study area is covered with croplands, settlements, water bodies and bare lands which are related to the physiographic and geomorphic evolution of the land surface. In the satellite images, it is possible to identify land use (crops, forest, water bodies, and bare fields), whereas identification of geomorphic features relies on indirect approaches based on the pattern of land use. Visual analysis, image classification and NDVI have been used to identify different geomorphic features which are manually digitized and presented on a map. The major boundaries between geomorphic units are qualitatively defined by sharp changes in tone. A list of the geomorphic features identified in the study area (Table 1) and the criteria for identifying them from the satellite images are discussed below.

The natural levees are high land compared to surrounding floodplain and are generally unaffected during
Fig. 4 Borehole locations with depth and section lines

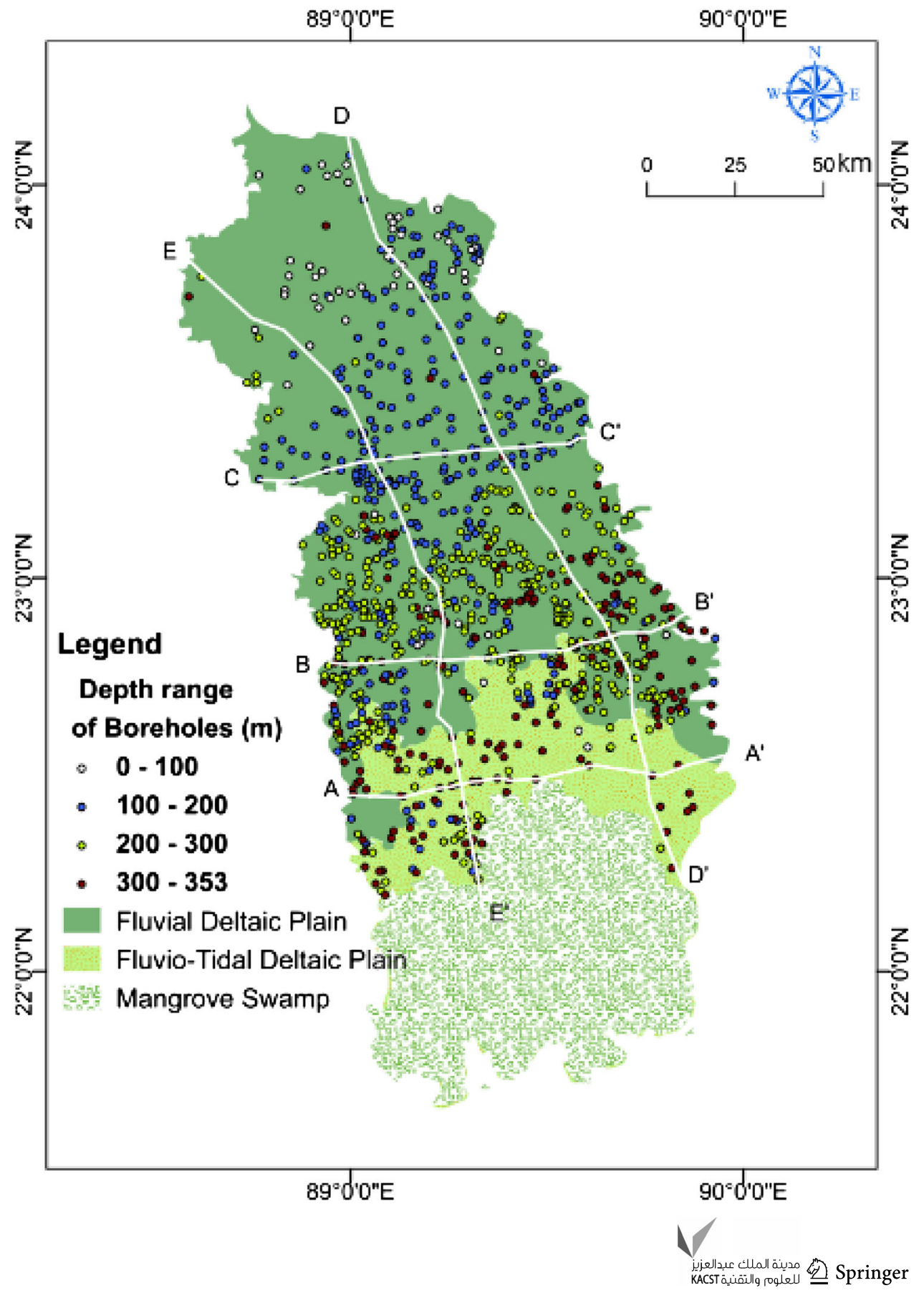


normal flood and are preferred by the people to build their settlements, mainly to avoid flooding. The settlements are typically surrounded by light to moderate vegetation including fruit trees and other hardwood trees. Linear pattern of these trees was compared with river alignment. In color infrared (CIR) combination of Landsat 8 imagery, curve shaped distribution of red tones parallel to river channels represents vegetation on natural levees and sporadic white tones within those red tones indicate settlements. In the satellite images, ox-bow lakes are identified by their characteristic shape. Meandering scrolls are identified by their characteristic shape of alternating ridges and swales. Vegetation on arc shaped ridges of meandering scrolls has been identified by red tone in CIR composite of
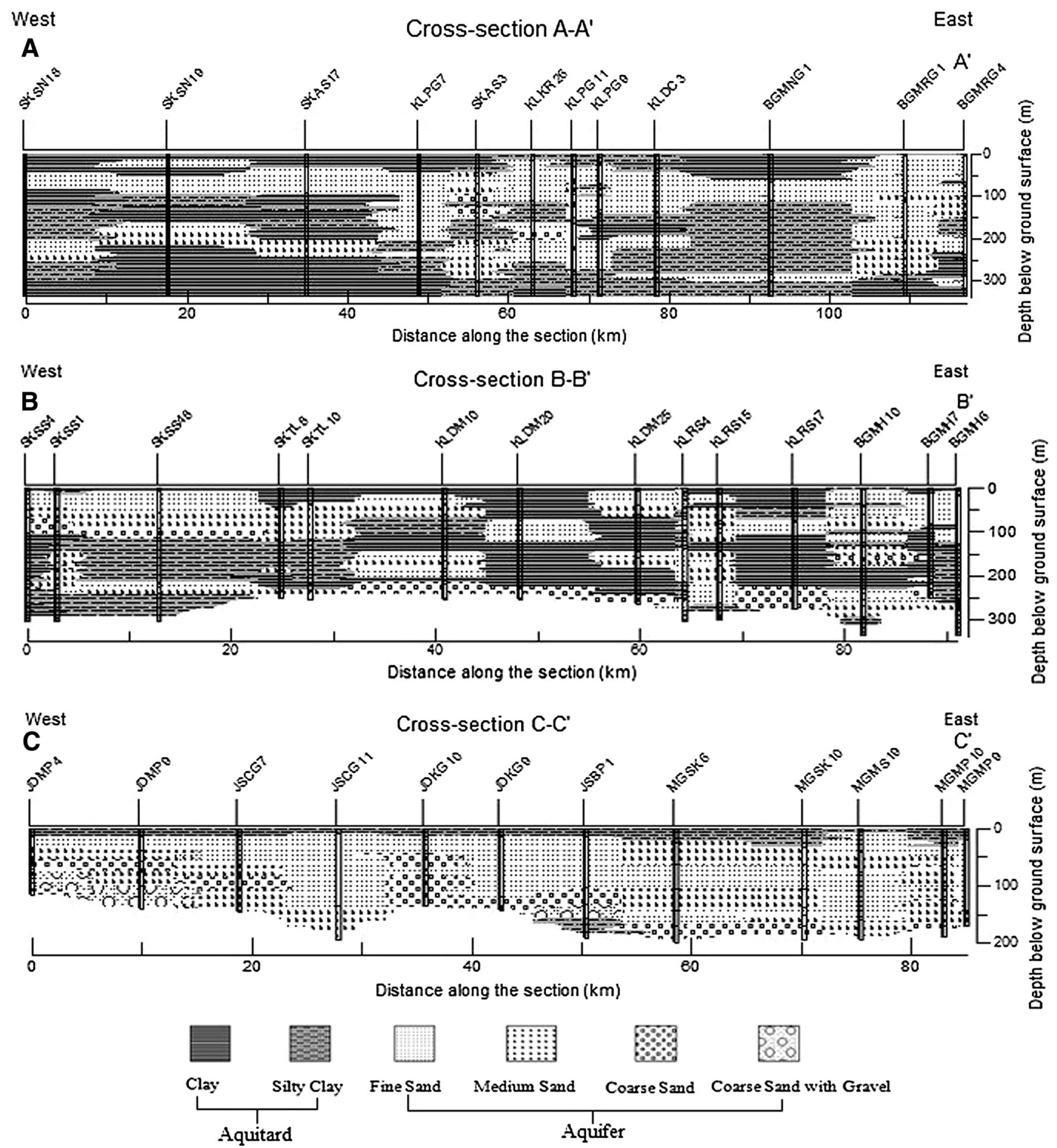

Fig. 5 EW cross sections along $\mathrm{AA}^{\prime}, \mathrm{BB}^{\prime}$, and $\mathrm{CC}^{\prime}$ transects 

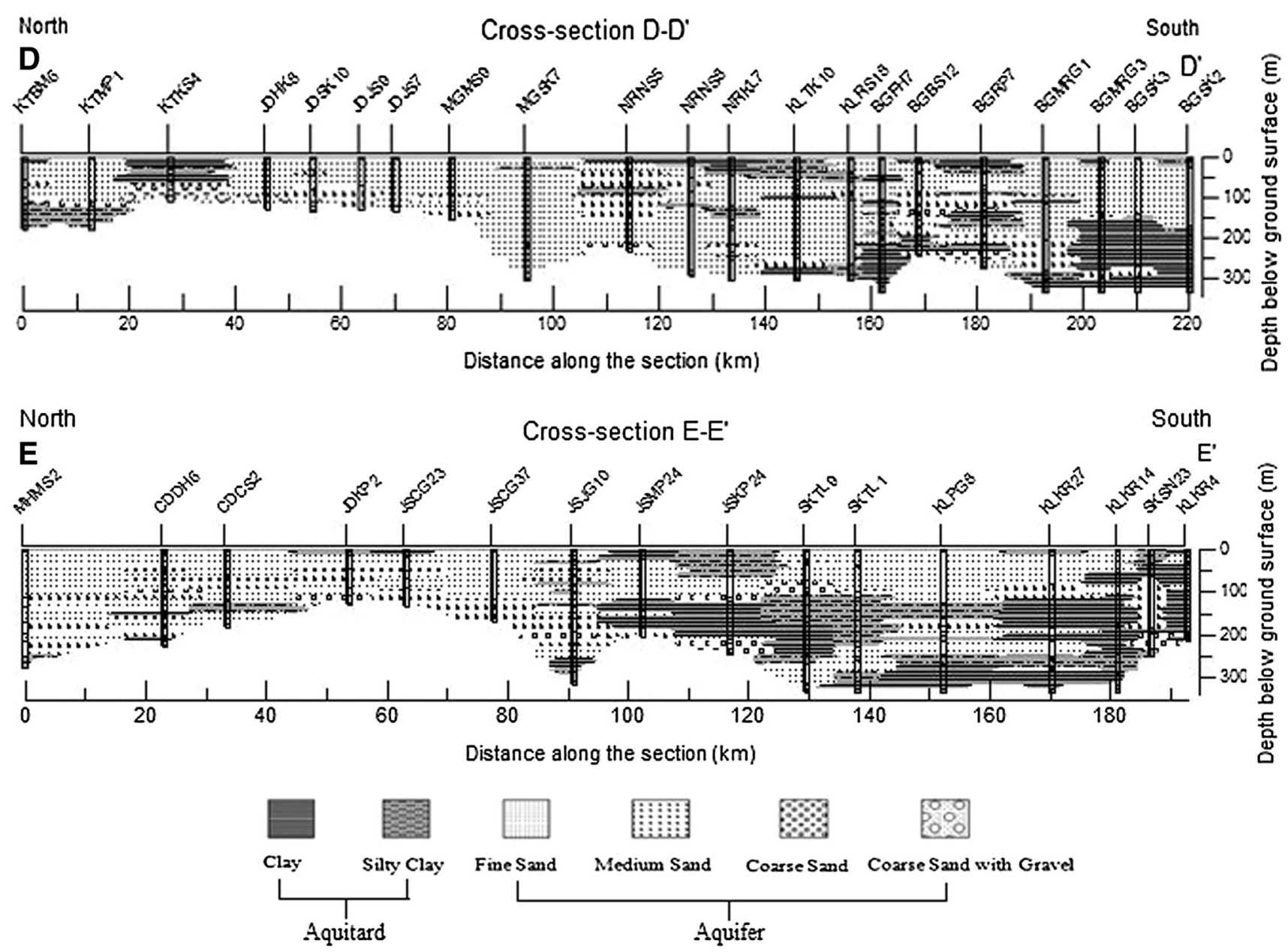

Fig. 6 NS cross sections along $\mathrm{DD}^{\prime}$, and $\mathrm{EE}^{\prime}$ transects

Landsat 8 imagery. Swales are identified by their existence in between ridges. In CIR band combination of Landsat 8 imagery bright white reflection from elongated area within the river channel is considered to identify channel bars. The mangrove swamp is criss-crossed by innumerable tidal rivers and creeks. Deeper red color in CIR band combination of Landsat 8 imagery and high NDVI (around 0.68) values indicate mangrove swamp area. The low-lying floodplains adjacent to natural levees may contain marshy areas known as backswamps. They are identified based on scattered light reddish tones within black tones in Landsat 8 imagery with CIR band combination and through unsupervised classification. After identification of backswamp, ox-bow lake and mangrove swamp, remaining water logged area is described as other wetland.

\section{Geomorphological mapping}

A regional geomorphological map of the WGD was developed by overlapping digitized layers of identified geomorphic features (Fig. 2). Based on identified

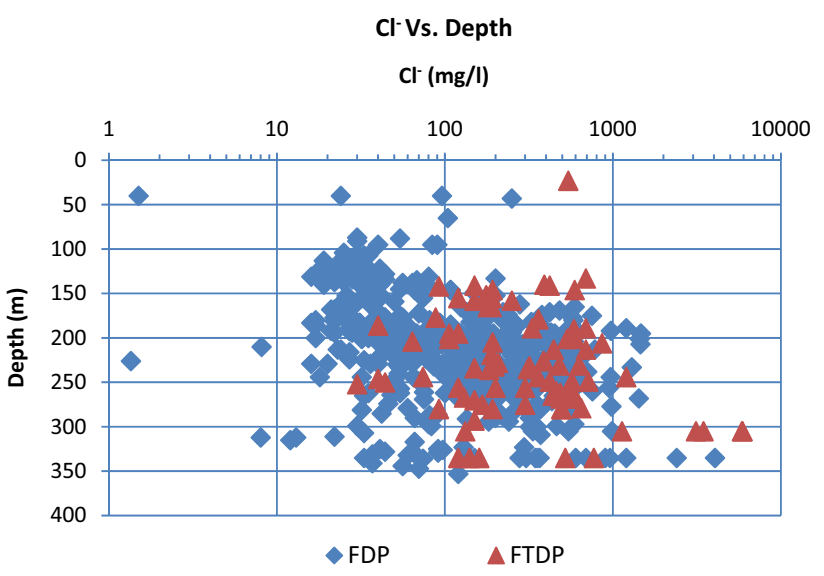

Fig. 7 Depth distribution of chloride concentrations in groundwater of the study area

characteristic geomorphic features the WGD is divided into two broad geomorphic units viz. fluvial or upper deltaic plain (FDP) and fluvio-tidal or lower deltaic plain (FTDP) (Fig. 3). The boundary between FDP and FTDP was drawn 
considering the inland limit of saline influences (about $3 \mathrm{~m}$ above mean sea level) and the distribution of tidal channels and creeks (Allison 1998; Allison et al. 2003). Though mangrove swamp is a part of the fluvio-tidal deltaic plain; it is included in Fig. 3 because of its larger areal extent. The FDP is characterized by ox-bow lakes, meandering scrolls, natural levees, backswamps, etc.

FDP is formed by the deposition of present and past meandering rivers and is drained by the major distributaries and sub-distributaries of the Ganges river such as the Madhumati, Betna, and Bhairab rivers. On the other hand, the FTDP is formed by the deposition of fluvial rivers as well as tides. FTDP is distinguished by mangrove swamp, and numerous tidal canals and creeks. The lower parts of the major distributaries and sub-distributaries of the Ganges river like the Haringhata, Burishwar, Bishkhali, Tetulia, Pusur, Shibsa, and Hariabhanga rivers drain the FTDP. Following the recognition and delineation of aforementioned geomorphic features, remaining areas in FDP and FTDP are defined as river floodplain and tidal floodplain, respectively.

\section{Hydrostratigraphy}

The lithologic cross sections prepared from borelogs represent subsurface stratigraphic characteristics of the study
Fig. 8 Spatial distribution map of chloride concentrations at various depths in relation to geomorphic units

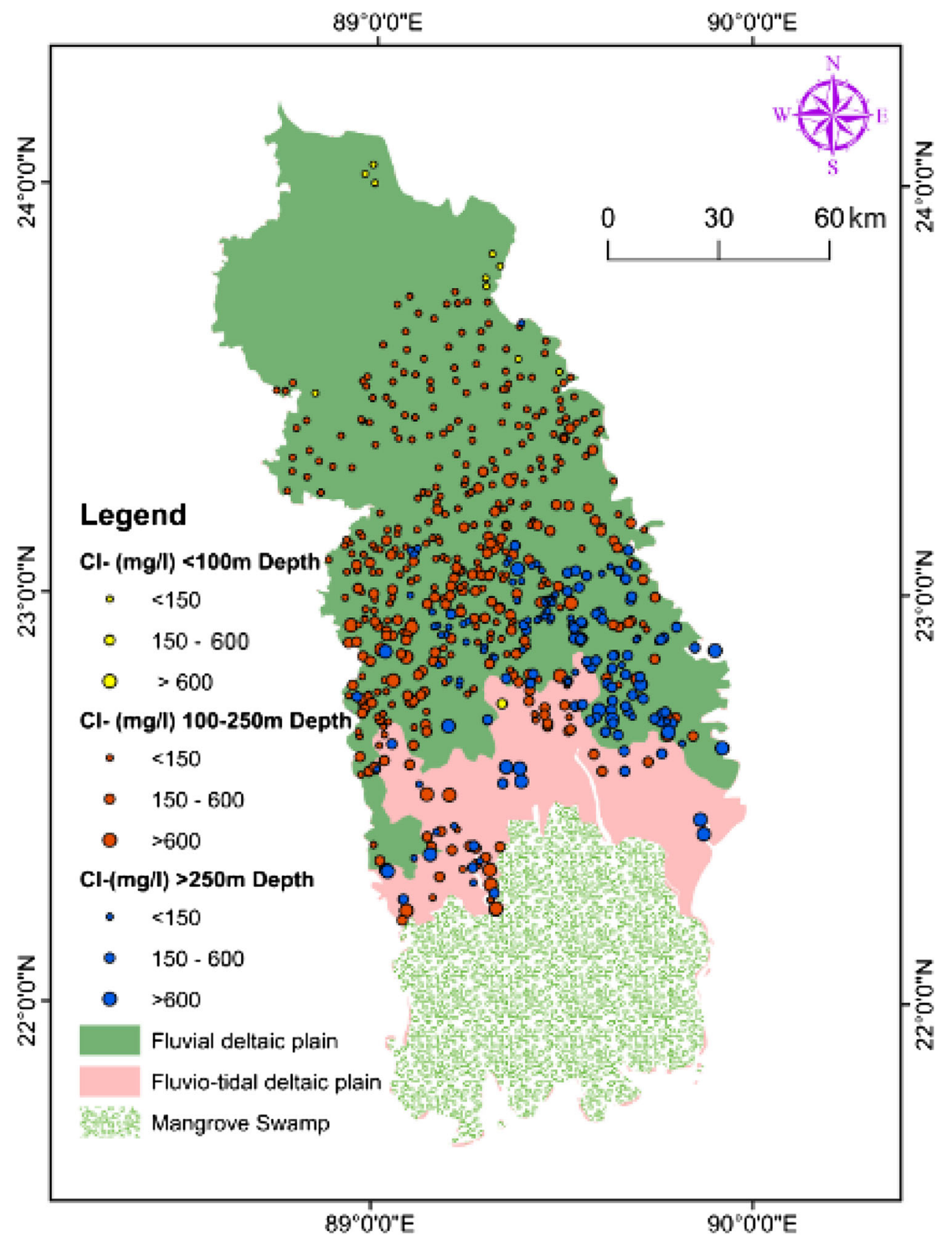


area. They also provide detailed picture of the aquifer framework (Mukherjee et al. 2007), i.e., hydrostratigraphic settings. Due to the absence of reliable dates for aquifer sediments from different depths, the delineation of hydrostratigraphy of the study area has been based on sediment grain size. The lithology of the borelogs is recorded at sub-meter vertical resolution and it consists of six major types of unconsolidated sediments: coarse sand with gravel, coarse sand, medium sand, fine sand, silty clay and clay. From the hydrostratigraphic point of view, these sediments have been categorized as aquifer (sand and gravel) and aquitard (clay and silty clay). Sediment color has not been documented in the borelogs. For the purpose of this study, only the major sediment types are used for identifying the various hydrostratigraphic units. A relatively thin soil horizon with a typical thickness of 2-3 m covers the study area; this soil horizon has not been described separately, rather it is merged with the top clay layer. Two north-south and three east-west manually correlated lithologic section lines (Fig. 4) have been constructed to identify variations in hydrostratigraphy between FDP and FTDP along with variations in each unit.

\section{EW cross sections}

Three transects viz. $\mathrm{AA}^{\prime}, \mathrm{BB}^{\prime}, \mathrm{CC}^{\prime}$ (Fig. 5) are constructed considering the geomorphology of the study area: transect $\mathrm{AA}^{\prime}$ passes through the fluvio-tidal deltaic plain; transect $\mathrm{BB}^{\prime}$ goes through the transitional zone between FDP and FTDP; and $\mathrm{CC}^{\prime}$ cross section depicts fluvial deltaic plain area.

At the top of section $\mathrm{AA}^{\prime}$ that characterizes FTDP, a discontinuous clay layer extends from the surface to a depth of about 6-67 m. A thick sandy deposit extending from east to west at about $6 \mathrm{~m}$ to more than $150 \mathrm{~m}$ depth underlying the surficial aquitard serves as the main regional aquifer. In many places, this main aquifer has been separated into multiple layers by the occurrence of extensive, thick, discontinuous aquitards of varying depths (between 100 and $300 \mathrm{~m}$ ). The deeper aquifers are interconnected and confined to semi-confined in nature. An extensive, thick basal clay/silty clay layer at around $300 \mathrm{~m}$ depth marks the division between the aquifers above and below this aquitard. Overall, the section shows that the fluviotidal deltaic plain is dominated by clay to silty clay deposits and characterized by a complex multi-aquifer system of confined to semi-confined nature.

The top most aquitard is relatively thin and discontinuous along the section $\mathrm{BB}^{\prime}$. This section is also dominated by clay and silty clay deposits and characterized by intercalation of clay, silty clay and sand layers of varying thickness. The most noteworthy characteristic of this section is the presence of isolated sand bodies of various sizes at different depths where the aquifers are patchy in nature and occur at different depths.

In section $\mathrm{CC}^{\prime}$ that represents the FDP, the upper clay layer is very thin and its thickness, in general, increases from east to west from about 6-18 m. Just below this uppermost aquitard, the whole section is dominated by sandy deposits mostly consisting of fine to coarse grained sand. Moreover, two gravel horizons occur at depths of about 100-150 m, probably indicating paleo-channels (Mukherjee et al. 2007). Though this huge sandy deposit is separated in some places by thin and discontinuous clay and silty clay layers, it may be considered as a single aquifer system.

\section{NS cross sections}

Two north-south trending cross sections (Fig. 6) are constructed for the study area keeping alignment almost parallel to the Gorai-Modhumati river covering the major geomorphic units. The cross sections $\mathrm{DD}^{\prime}$ and $\mathrm{EE}^{\prime}$ pass through the eastern and the western part of the study area, respectively. It is clearly seen from the cross sections that proportions of fine grain particles increase (but coarse grain particles decrease) towards south as it approaches from fluvial to tide dominated area. The aquifer changes gradually from unconfined to semi-confined/confined character towards the south. The northern part shows single aquifer system and aquifer complexity increases towards the south where it ends up as a multi-layer aquifer system.

Several studies in Bangladesh (Ravenscroft 2003; Ahmed et al. 2004; Shamsudduha and Uddin 2007; Shamsudduha et al. 2011; Ayers et al. 2016) and West Bengal (Acharyya et al. 2000; Bhattacharya et al. 1997; Goodbred et al. 2003; Shamsudduha and Uddin 2007; Biswas et al. 2014; Ghosal et al. 2015) have stated the existence of multi-aquifer system in the Ganges Delta

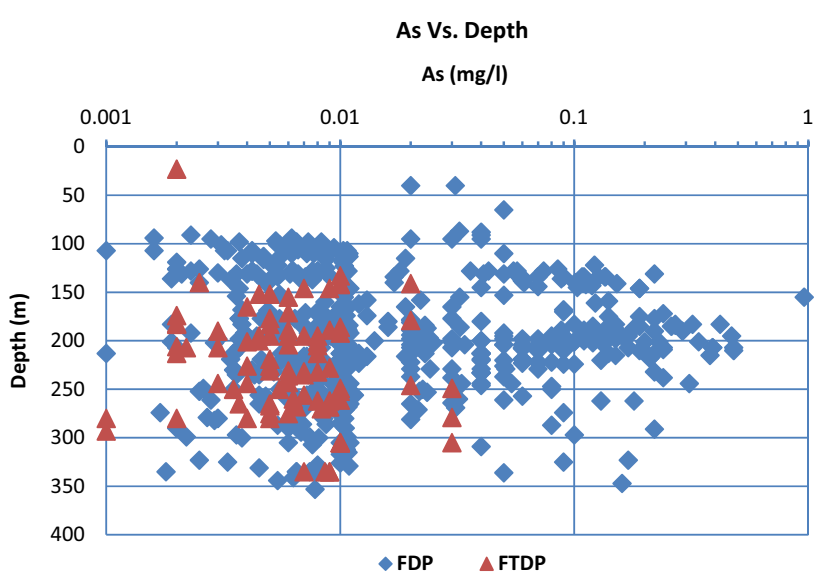

Fig. 9 Depth distribution of arsenic concentrations in groundwater of the study area

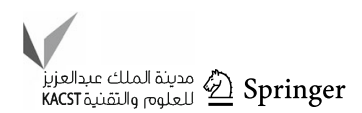


plain. Generalized classification schemes define two aquifer units: shallow aquifers (occurring within a depth of $150 \mathrm{~m}$ ) and deep aquifers (occurring at depths below $150 \mathrm{~m}$ ) in Bangladesh (Ahmed et al. 2004). On the contrary, Michael and Voss (2009) have represented the aquifer system in Bangladesh as a single, homogeneous, anisotropic aquifer extending over the entire basin. Mukherjee et al. (2007) have mentioned the presence of a major single aquifer system in the Western Bengal Basin and the increase of complexity and locally division into multi-aquifer system towards south. However, none of the study has completely described the hydrostratigraphic differences between the upper and lower Ganges Delta plain.

In summary, based on the previously described lithologic cross sections, significant difference in hydrostratigraphy has been identified for FDP and FTDP. The FDP is characterized by a major single aquifer system, which is mostly unconfined to semi-confined in nature. It comprises of a composite sequence of meandering river-born deposits with a dominance of coarser grained particles, which forms most of the hydrostratigraphic unit (Bhattacharya et al. 1997). One the other hand, FTDP is distinguished by a
Fig. 10 Spatial distribution map of arsenic concentrations at various depths in relation to geomorphic units

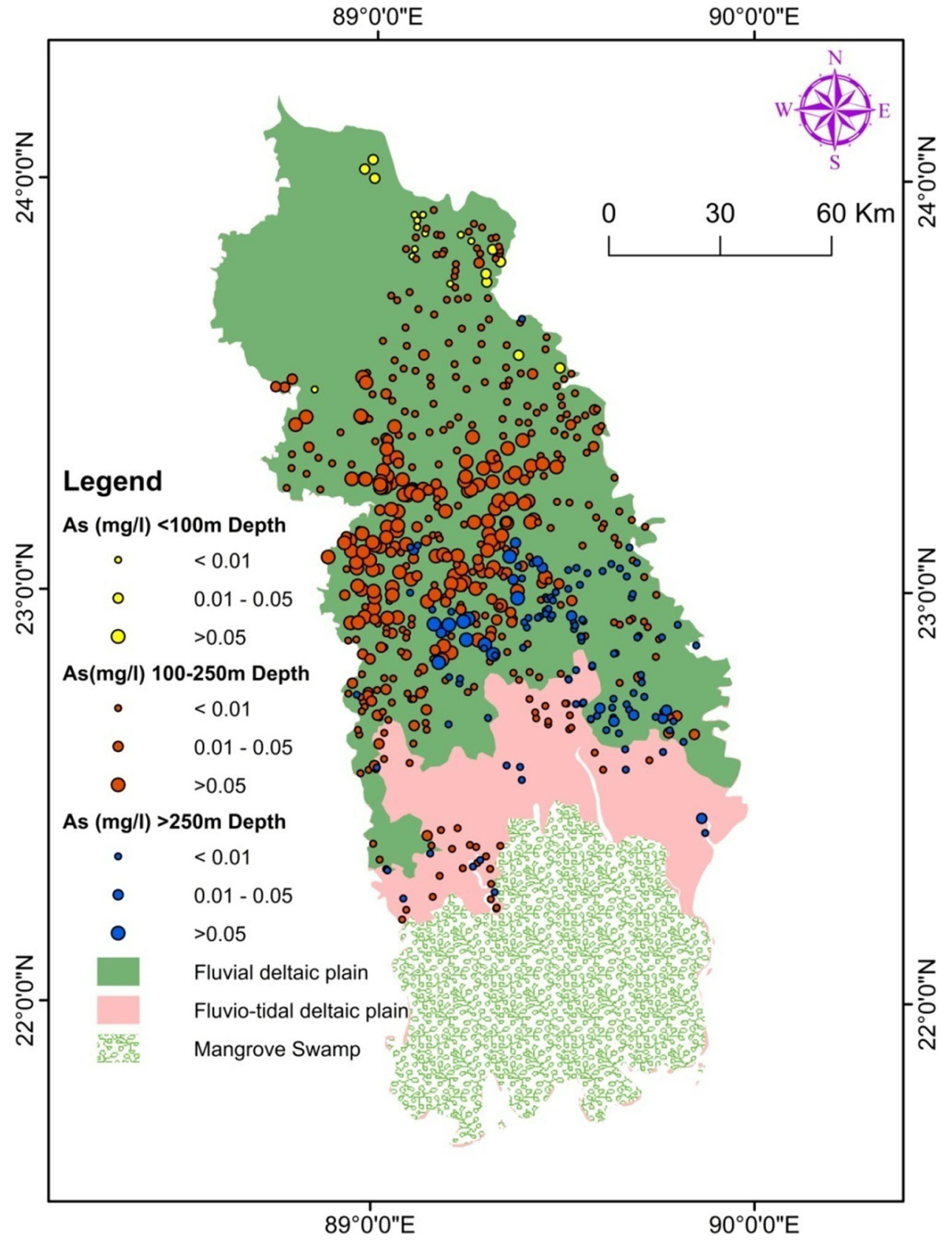


complex multi-aquifer system of confined to semi-confined nature. The FTDP comprises of a complicated mud-sand stratigraphy, which have resulted from tidal channels, eustatic influence and marine transgression (Allison et al. 2003; Goodbred et al. 2003, 2014; Umitsu 1993a, b; Islam and Tooley 1999; Goodbred and Kuehl 2000).

\section{Groundwater quality}

High salinity, arsenic and iron in groundwater are the major water quality constraints in the study area for drinking purposes (e.g., Smith et al. 2000; Ravenscroft 2003, Ravenscroft et al. 2005). The status of the water quality parameters in groundwater of the major geomorphic units is discussed focusing their vertical and spatial distribution pattern considering WHO (2011) and Bangladesh drinking water standards (BDWS) (DoE 1997).

\section{Salinity}

Depth distribution pattern of chloride concentration (Fig. 7) in the groundwater of FDP and FTDP does not show any distinct trend with depth. However, a significant number of groundwater samples from FDP at depths greater than $100 \mathrm{~m}$ are relatively low in chloride concentrations $(<100 \mathrm{mg} / \mathrm{l})$ but majority of the samples from FTDP at similar depths show higher chloride concentrations ( $>100 \mathrm{mg} / \mathrm{l})$. Almost, $17 \%$ of 86 samples in the FTDP exceed the upper limit of BDWS for chloride $(600 \mathrm{mg} / \mathrm{l})$ but only about $4 \%$ of 529 samples in the FDP go above the same limit.

Spatial distribution map of chloride concentrations (Fig. 8) at various depths show that concentration is comparatively low in FDP, but it gradually increases towards south, i.e., in the FTDP as it approaches the coastal plain. However, a high heterogeneity in distribution of chloride concentrations is also evident which needs additional investigations. But high chloride concentration in FTDP is rather depth not geomorphically controlled.

\section{Arsenic}

About $83 \%$ wells having depth greater than $100 \mathrm{~m}$ in the FTDP show low As concentration $(<0.01 \mathrm{mg} / \mathrm{l})$ in groundwater and none of the 89 samples in FTDP exceeds BDWS for As $(0.05 \mathrm{mg} / \mathrm{l})$. On the contrary, 27\% of 553 wells in FDP with depths greater than $100 \mathrm{~m}$ show high arsenic concentrations $(>0.05 \mathrm{mg} / \mathrm{l})$ in groundwater (Fig. 9).

Spatial distribution map of groundwater arsenic concentrations (Fig. 10) show elevated As concentrations mostly in the southwestern part of the FDP covering Jessore district and adjoining areas. Almost $50 \%$ of the wells with depths greater than $100 \mathrm{~m}$ in those particular areas exceed BDWS for As concentration.

Generally, in Bangladesh and West Bengal state of India, high As concentration occurs mostly in shallow aquifers at depths less than $100 \mathrm{~m}$ (Bhattacharya et al. 1997; BGS/DPHE 2001; van Geen et al. 2003; Ahmed et al. 2004; Biswas et al. 2014). Occurrence of high arsenic in aquifer at greater depths $(>100 \mathrm{~m})$ in the FDP, particularly in Jessore and adjoining areas, is unusual and it is comparable with high As concentrations at Chakdaha block of West Bengal, India (Biswas et al. 2014) located just west of Jessore district in Bangladesh. Analysis of several lithologs (Fig. 5 section $\mathrm{CC}^{\prime}$ ) reveals that the aquifer system in this area is underlain by a clay layer of variable thickness $(0-20 \mathrm{~m})$ and is composed of sands, gravelly sands with little or no clay down to a depth of $200 \mathrm{~m}$. The absence of any prominent impermeable layer between the shallow and deeper part of the aquifer system results in an overall higher permeability and lower vertical anisotropy that make aquifer systems hydrodynamically connected allowing vertical contamination of arsenic from the shallow into the deeper part of the aquifer system.

\section{Iron}

Iron concentrations in groundwater of the study area do not show any particular relationship with depth. Iron concentrations are slightly higher in the study area, a common characteristic of water in many parts of Bangladesh. Approximately, 29\% of 85 samples in the FTDP exceed the upper limit of BDWS for iron $(1 \mathrm{mg} / \mathrm{l})$, while the percentage is above 35 for the 566 samples of the FDP (Fig. 11).

Spatial distribution map of iron concentrations at various depths does not show any particular trend in relation to geomorphology (Fig. 12).

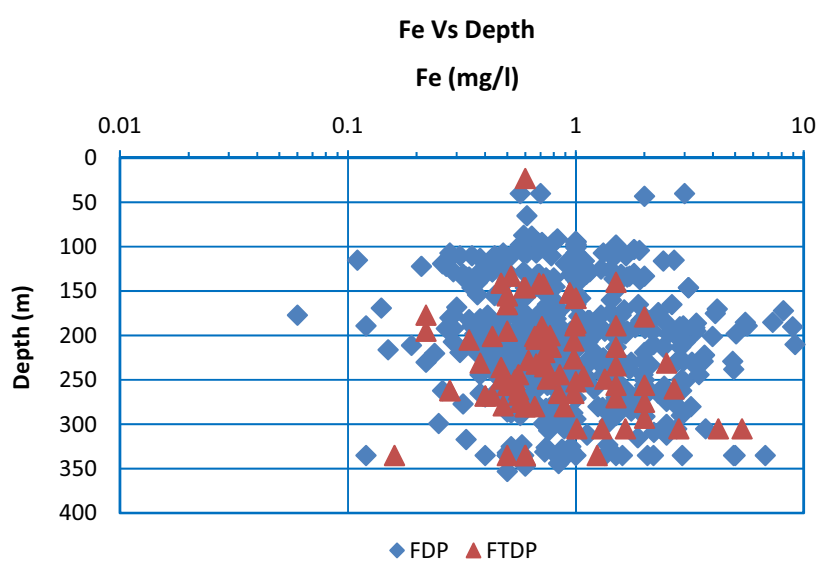

Fig. 11 Depth distribution of iron concentrations in groundwater of the study area 
Fig. 12 Spatial distribution map of iron concentrations at various depths in relation to geomorphic units

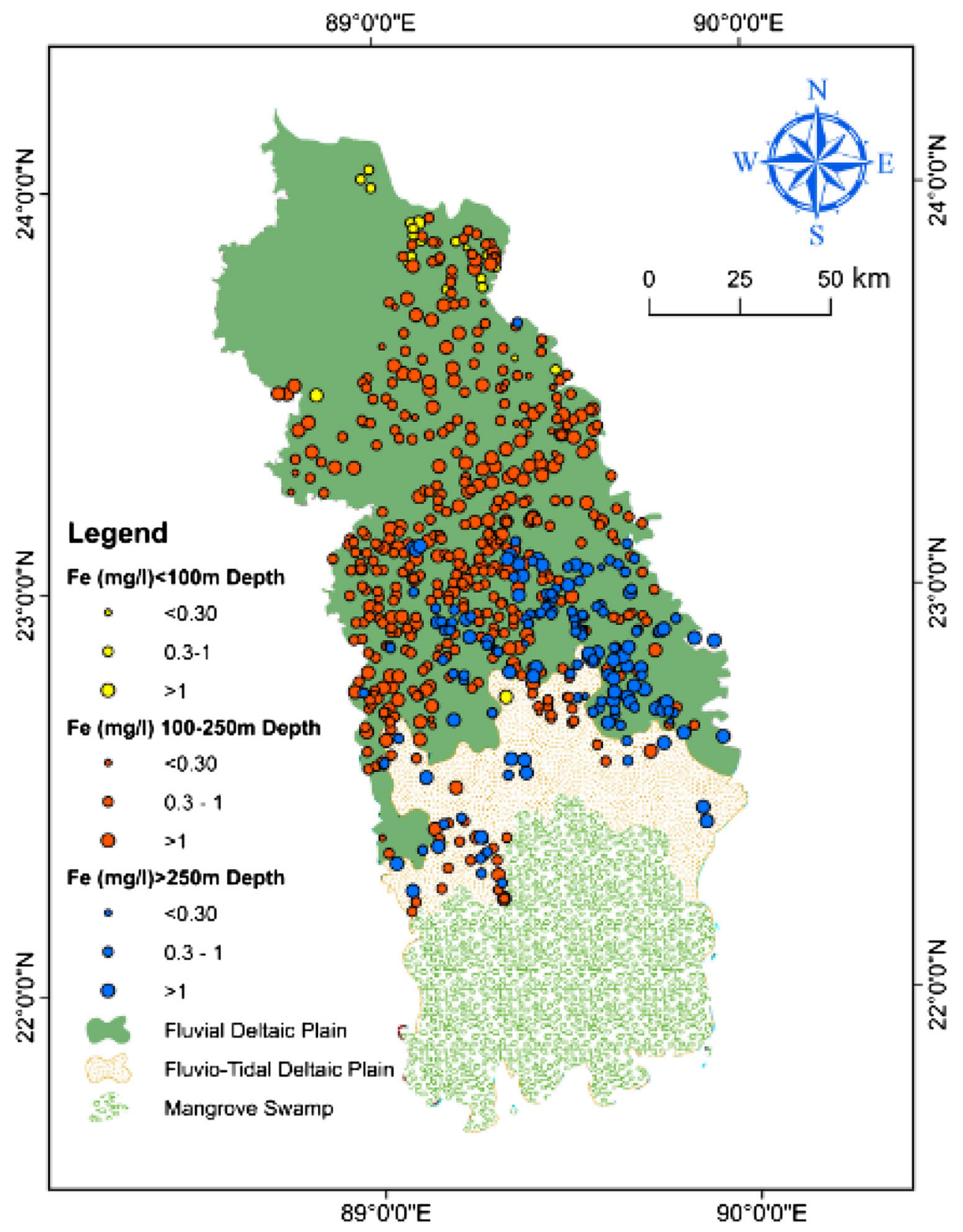

\section{Conclusions}

Geomorphic evolution of the WGD is complex and has been affected by various processes and factors like shifting of the rivers, sediments load carried by rivers, neotectonic activities, sea-level changes, etc. All these factors can bring in different hydrostratigraphy and groundwater quality under varying geomorphic conditions.

The study area has been divided into two broad geomorphic units: the fluvial deltaic plain (FDP) and the fluvio-tidal deltaic plain (FTDP) based on the characteristic geomorphic features. FDP is characterized by dominance of larger percentage of coarser (sandy) channel deposits, while FTDP is distinguished by alternating sand and clay layers and relatively greater percentage of finer overbank deposits (silt and clay). Hydrostratigraphically, the FDP is characterized by a single aquifer system whereas the FTDP shows a complex multi-aquifer system.

Occurrence of elevated As concentration at greater depths mostly in the southwestern part of the fluvial deltaic plain demonstrates relationship with geomorphology and aquifer geometry. Gradual increase in salinity from FDP to FTDP is related to tide and sea water intrusion. Though iron concentration does not show any particular spatial relationships, considerable amount of samples both in FDP and FTDP shows little high iron concentrations. As there 
are notable variations in water quality parameters, detailed investigations involving larger number of samples and isotopic analysis can put further light on the causative reasons for such variations.

Acknowledgements This paper is based on the results of a Master's thesis of the first author. We acknowledge DPHE (Department of Public Health and Engineering, Bangladesh) for providing data. We appreciate the helpful remarks and suggestions of the anonymous reviewers.

Open Access This article is distributed under the terms of the Creative Commons Attribution 4.0 International License (http:// creativecommons.org/licenses/by/4.0/), which permits unrestricted use, distribution, and reproduction in any medium, provided you give appropriate credit to the original author(s) and the source, provide a link to the Creative Commons license, and indicate if changes were made.

\section{References}

Acharyya SK, Shah BA (2007) Groundwater arsenic contamination affecting different geologic domains in India-a review: influence of geological setting, fluvial geomorphology and Quaternary stratigraphy. J Environ Sci Health 42(12):1795-1805. doi:10.1080/10934520701566744

Acharyya SK, Lahiri S, Raymahashay BC, Bhowmik A (2000) Arsenic toxicity of groundwater in parts of the Bengal basin in India and Bangladesh: the role of Quaternary stratigraphy and Holocene sea-level fluctuation. Environ Geol 39(10):1127-1137. doi: $10.1007 / \mathrm{s} 002540000107$

Ahmed KM, Imam MB, Akhter SH, Hasan MA, Khan AA (2001) Sedimentology and mineralogy of arsenic contaminated aquifers in the Bengal Delta of Bangladesh. In: Jacks G, Bhattacharya P, Khan AA (eds) Groundwater arsenic contamination in the Bengal Delta plain of Bangladesh. Proc KTH-Dhaka University Seminar. KTHSpecial Publication, TRITA-AMI Report 3084, pp 97-108

Ahmed KM, Bhattacharya P, Hasan MA, Akhter SH, Alam SMM, Bhuyian MAH, Imam MB, Khan AA, Sracek O (2004) Arsenic enrichment in groundwater of the alluvial aquifers in Bangladesh: an overview. Appl Geochem 19(2):181-200. doi:10.1016/ j.apgeochem.2003.09.006

Alam M, Alam MM, Curray JR, Chowdhury MLR, Gani MR (2003) An overview of the sedimentary geology of the Bengal Basin in relation to the regional techtonic framework and basin-fill history. Sediment Geol 155(3):179-208. doi:10.1016/S00370738(02)00180-X

Allison MA (1998) Geologic framework and environmental status of the Ganges-Brahmaputra Delta. J Coast Res 14(3):826-836

Allison MA, Khan SR, Goodbred SL Jr, Kuehl SA (2003) Stratigraphic evolution of the late Holocene Ganges Brahmaputra lower delta plain. Sediment Geol 155:317-342. doi:10.1016/ S0037-0738(02)00185-9

Ayers JC, Goodbred S, George G, Fry D, Benneyworth L, Hornberger G, Roy K, Karim MR, Akter F (2016) Source of salinity and arsenic in groundwater in southwest Bangladesh. Geochem Trans 17:4. doi:10.1186/s12932-016-0036-6

BGS/DPHE (2001) Arsenic contamination of groundwater in Bangladesh, WC/00/19. British Geological Survery, Keyworth

Bhattacharya P, Chatterjee D, Jacks G (1997) Occurrence of arseniccontaminated groundwater in alluvial aquifers from the delta plains, eastern India: options for safe drinking water supply. Int J Water Resour Dev 13(1):79-92. doi:10.1080/07900629749944

Biswas A, Bhattacharya P, Mukherjee A, Nath B, Alexanderson N, Kundu AK, Chatterjee D, Jacks G (2014) Shallow hydrostratigraphy in an arsenic affected region of Bengal Basin: implication for targeting safe aquifers for drinking water supply. Sci Total Environ 485-486:12-22. doi:10.1016/j.scitotenv.2014.03.045

Brammer H, Ravenscroft P (2009) Arsenic in groundwater: a threat to sustainable agriculture in South and South-east Asia. Environ Int 35(3):647-654. doi:10.1016/j.envint.2008.10.004

Burgess WG, Burren M, Perrin J, Ahmed KM (2002) Constraints on sustainable development of arsenic-bearing aquifers in southern Bangladesh. Part 1: a conceptual model of arsenic in the aquifer. In: Hiscock KM, Rivett MO, Davison RM (eds) Sustainable groundwater development, 193. Geological Society, London, Special Publications, pp 145-163. doi: 10.1144/GSL.SP.2002. 193.01.12

Burgess WG, Hoque MA, Michael HA, Voss CI, Breit GN, Ahmed KM (2010) Vulnerability of deep groundwater in the Bengal Aquifer System to contamination by arsenic. Nat Geosci 3:83-87. doi:10.1038/ngeuo750

Cuthbert MO, Burgess WG, Connell L (2002) Constraints on sustainable development of arsenic-bearing aquifers in southern Bangladesh. Part 2: preliminary models of arsenic variability in pumped groundwater. In: Hiscock KM, Rivett MO, Davison RM (eds) Sustainable groundwater development, vol. 193. Geological Society, London, Special Publications, pp 165-179. doi:10. 1144/GSL.SP.2002.193.01.13

Das B, Rahman MM, Nayak B, Pal A, Chowdhury UK, Mukherjee SC, Saha KC, Pati S, Quamruzzaman Q, Chakraborti D (2009) Groundwater arsenic contamination, its health effects and approach for mitigation in West Bengal, India and Bangladesh. Water Qual Expo Health 1(1):5-21. doi:10.1007/s12403-0080002-3

DoE (1997) Bangladesh drinking water standards. Ministry of Environment and Forests. Government of the People's Republic of Bangladesh. http://www.doe.gov.bd

Ghosal U, Sikdar PK, McArthur JM (2015) Paleosol control of arsenic pollution: the Bengal Basin in West Bengal, India. Groundwater 53(4):588-599. doi:10.1111/gwat.12251

Goodbred SL Jr, Kuehl SA (2000) The Significance of large sediment supply, active tectonism, and eustasy on margin sequence development: late Quaternary stratigraphy and evaluation of the Ganges-Brahmaputra Delta. Sediment Geol 133:227-248. doi:10.1016/S0037-0738(00)00041-5

Goodbred SL, Kuehl SA, Steckler MS, Sarkar MH (2003) Controls on facies distribution and stratigraphic preservation in the GangesBrahmaputra Delta sequence. Sediment Geol 155(3-4):301-316. doi:10.1016/S0037-0738(02)00184-7

Goodbred SL, Paolo PM, Ullah MS, Pate RD, Khan SR, Kuehl S, Singh A (2014) Piecing together the Ganges-BrahmaputraMeghna River Delta: use of sediment provenance to reconstruct the history and interaction of multiple fluvial systems during Holocene delta evolution. Geol Soc Am Bull 32:16

Harvey CF, Ashfaque KN, Yu W, Badruzzaman ABM, Ali MA, Oates PM, Michael HA, Neumann RB, Beckie R, Islam S, Ahmed MF (2006) Groundwater dynamics and arsenic contamination in Bangladesh. Chem Geol 228(1):112-136. doi:10.1016/ j.chemgeo.2005.11.025

Hasan MA, Ahmed KM, Sracek O, Bhattacharya P, von Brömssen M, Broms S, Fogelstrom J, Mazumder ML, Jacks G (2007) Arsenic in shallow groundwater of Bangladesh: investigations from three different physiographic settings. Hydrogeol J 15(8):1507-1522. doi:10.1007/s10040-007-0203-z

Hoque MA (2010) Models for managing deep aquifer in Bangladesh, Unpubl. Ph.D. Thesis. University College London, UK 
Hoque MA, Burgess WG, Shamsudduha M, Ahmed KM (2011) Delineating low-arsenic groundwater environments in the Bengal Aquifer System, Bangladesh. Appl Geochem 26:614-623. doi:10.1016/j.apgeochem.2011.01.018

Islam MS, Tooley MJ (1999) Coastal and sea level changes during the Holocene in Bangladesh. Quat Int 55:61-75

Jha VC, Bairagya HP (2011) Flood plain evaluation in the GangaBrahmaputra Delta: a tectonic review. EJESM 4(3):12-24. doi:10.4314/ejesm.v4i3.3

JICA (2002) The study on the ground water development of deep aquifers for safe drinking water supply to arsenic affected areas in western Bangladesh. Draft final report, book 1-3. Japan International Cooperation Agency, Kokusai Kogyo Co. Ltd. and Mitsui Mineral Development Engineering Co. Ltd

McArthur JM, Ravencroft P, Safiullah S, Thirlwall MF (2001) Arsenic in groundwater: testing pollution mechanism for sedimentary aquifers in Bangladesh. Water Resour Res 37:109-117

McArthur JM, Ravenscroft P, Banerjee DM, Milsom J, HudsonEdwards KA, Sengupta S, Bristow C, Sarkar A, Tonkin S, Purohit R (2008) How paleosols influence groundwater flow and arsenic pollution: a model from the Bengal Basin and its worldwide implication. Water Resour Res 44:W11411. doi:10. 1029/2007WR006552

Michael HA, Voss CI (2008) Evaluation of the sustainability of deep groundwater as an arsenic-safe resource in the Bengal Basin. Proc Natl Acad Sci 105:8531-8536. doi:10.1073/pnas.0710477105

Michael H, Voss C (2009) Controls on groundwater flow in the Bengal Basin of India and Bangladesh: regional modeling analysis. Hydrogeol J 17:1561-1577. doi:10.1007/s10040-008$0429-4$

Mukherjee A (2006) Deeper groundwater flow and chemistry in the arsenic affected Western Bengal Basin, West Bengal, India, Unpubl. Ph.D. Thesis. University Kentucky, Lexington, USA

Mukherjee A, Fryar AE, Howell P (2007) Regional hydrostratigraphy and groundwater flow modeling of the arsenic affected Western Bengal Basin, West Bengal, India. Hydrogeol J 15:1397-1418. doi:10.1007/s10040-007-0208-7

Muley RB, Babar MD, Atkore SM, Ghute BB (2010) Application of remote sensing and hydrogeological characteristics for groundwater Potential Zone in Purna Tahsil (Block) Parbhani District, Maharashtra. Proceeding volume of workshop on application of remote sensing and GIS in water resources management, held at Hyderabad, India, pp 28-36

Nishat A, Bhuiyan MA, Saleh FM (2003) Assessment of the groundwater resources of Bangladesh. In: Rahman AA, Ravenscroft P (eds) Groundwater resources development in Bangladesh. The University Press, Dhaka, pp 87-114

Ravenscroft P (2001) Distribution of groundwater arsenic in Bangladesh related to geology. In: Jacks G, Bhattacharya P, Khan AA (eds) Groundwater arsenic contamination in the Bengal Delta Plains of Bangladesh. Proc KTH-Dhaka University Seminar. KTHSpecial Publication, TRITA-AMI Report 3084, pp 41-56
Ravenscroft P (2003) Overview of the hydrogeology of Bangladesh. In: Rahman AA, Ravenscroft P (eds) Groundwater resources and development in Bangladesh-background to the arsenic crisis, agricultural potential and the environment. Bangladesh centre for advanced studies. University Press Ltd, Dhaka, pp 43-86

Ravenscroft P, Burgess WG, Ahmed KM, Burren M, Perrin J (2005) Arsenic in groundwater of the Bengal Basin, Bangladesh: distribution, field relations, and hydrogeological setting. Hydrogeol J 13:727-751. doi:10.1007/s10040-003-0314-0

Ravenscroft P, Brammer H, Richards KS (2009) Arsenic pollution: a global synthesis. London, Wiley-Blackwell, p 618

Rogers KG, Goodbred SL, Mondal DR (2013) Monsoon sedimentation on the 'abandoned' tide-influenced Ganges Brahmaputra Delta plain. Estuar Coast Shelf Sci 131:297-309. doi:10.1016/j. ecss.2013.07.014

Shamsudduha M, Uddin A (2007) Quaternary shoreline shifting and hydrogeologic influence on the distribution of groundwater arsenic in aquifers of the Bengal Basin. J Asian Earth Sci 31:177-194. doi:10.1016/j.jseaes.2007.07.001

Shamsudduha M, Marzen LJ, Uddin A, Lee MK, Saunders JA (2009) Spatial relationship of groundwater arsenic distribution with regional topography and water-table fluctuations in the shallow aquifers in Bangladesh. Environ Geol 57(7):1521-1535. doi:10. 1007/s00254-008-1429-3

Shamsudduha M, Taylor RG, Ahmed KM, Zahid A (2011) The impact of intensive groundwater abstraction on recharge to a shallow regional aquifer system: evidence from Bangladesh. Hydrogeol J 19:901-916. doi:10.1007/s10040-011-0723-4

Smedley PL, Kinniburgh DG (2002) A review of the source, behaviour and distribution of arsenic in natural water. Appl Geochem 17(5):517-568. doi:10.1016/SO883-2927(02)00018-5

Smith AH, Lingas EO, Rahman M (2000) Contamination of drinking water by arsenic in Bangladesh: a public health emergency. Bull WHO 78:1093-1103

Umitsu M (1993a) Late Quaternary sedimentary environments and landforms in the Ganges Delta. Sediment Geol 83(3-4):177-186. doi:10.1016/0037-0738(93)90011-S

Umitsu M (1993b) Late Quaternary sedimentary environments and landforms in the Ganges Delta. Sediment Geol 83:177-186

van Geen A, Zheng Y, Versteeg R, Stute M, Horneman A, Dhar R, Steckler M, Gelman A, Small C, Ahsan H, Graziano J, Hussein I, Ahmed KM (2003) Spatial variability of arsenic in 6000 tube wells in a $25 \mathrm{~km}^{2}$ area of Bangladesh. Water Resour Res 39(5):1140-1155. doi:10.1029/2002WR001617

van Wonderen JJ (2003) The use of groundwater models for resource assessment in Bangladesh. In: Rahman AA, Ravenscroft P (eds) Groundwater resource development in Bangladesh. The University Press, Dhaka, pp 127-140

WHO (2011) Water and sanitation guidelines for drinking-water quality. http://www.who.int/water-sanitationhealth/GDWQ/ Summary-tables/Sumtab.htm 